\title{
Coenzyme Q10 effects in neurodegenerative disease
}

This article was published in the following Dove Press journal:

Neuropsychiatric Disease and Treatment

6 November 2009

Number of times this article has been viewed

\author{
Meredith Spindler \\ $M$ Flint Beal ${ }^{1,2}$ \\ Claire Henchcliffe ${ }^{1,2}$ \\ 'Department of Neurology, \\ ${ }^{2}$ Department of Neuroscience, Weill \\ Medical College of Cornell University, \\ New York, NY, USA
}

\begin{abstract}
Coenzyme Q10 (CoQ10) is an essential cofactor in the mitochondrial respiratory chain, and as a dietary supplement it has recently gained attention for its potential role in the treatment of neurodegenerative disease. Evidence for mitochondrial dysfunction in neurodegenerative disorders derives from animal models, studies of mitochondria from patients, identification of genetic defects in patients with neurodegenerative disease, and measurements of markers of oxidative stress. Studies of in vitro models of neuronal toxicity and animal models of neurodegenerative disorders have demonstrated potential neuroprotective effects of CoQ10. With this data in mind, several clinical trials of CoQ10 have been performed in Parkinson's disease and atypical Parkinson's syndromes, Huntington's disease, Alzheimer disease, Friedreich's ataxia, and amyotrophic lateral sclerosis, with equivocal findings. CoQ10 is widely available in multiple formulations and is very well tolerated with minimal adverse effects, making it an attractive potential therapy. Phase III trials of high-dose CoQ10 in large sample sizes are needed to further ascertain the effects of CoQ10 in neurodegenerative diseases.
\end{abstract}

Keywords: coenzyme Q10, neurodegenerative disease, Parkinson's disease, Huntington's disease, mitochondrial dysfunction

\section{Introduction}

Over the past decade, interest in the roles of nutritional supplements in neurodegenerative disease has intensified. One of these supplements, coenzyme Q10 (CoQ10), is an essential cofactor involved in mitochondrial oxidative phosphorylation as well as a potent antioxidant. Strong evidence has now emerged supporting the role of oxidative stress and defective energy metabolism in the pathogenesis of many neurodegenerative disorders, such as Parkinson's disease (PD), Huntington's disease (HD), and Alzheimer disease (AD). There is, therefore, a robust scientific rationale for testing this agent as a potential neuroprotective therapy. Levels of CoQ10 in the brain and other tissues in humans and animals have been shown to decline with age, further suggesting a potential therapeutic role in age-related neurodegenerative disorders. ${ }^{1-3}$ Moreover, the substantia nigra, in which cell death results in the disabling motor symptoms of PD, has the lowest CoQ10 content within the brain. ${ }^{4}$ In light of these findings, in recent years a series of clinical trials have been undertaken in order to test CoQ10 effects in neurodegenerative disease. Here we review the most important clinical trials in neurodegenerative disease, their scientific underpinnings, and their implications for the future of treatment of patients suffering from neurodegenerative disease.
Correspondence: Meredith Spindler Department of Neurology, Weill Medical College of Cornell University, 525 East 68th Street, Suite F6I 0, New York, NY, USA Email mes905I@nyp.org 


\section{Coenzyme Q 10}

CoQ10 (2,3 dimethoxy-5-methyl-6-decaprenyl benzoquinone), also known as ubiquinone, is a lipid-soluble quinone composed of a redox active quinone ring and hydrophobic tail (Figure 1).$^{5-9}$ CoQ10, the predominant form of coenzyme Q in humans, contains 10 isoprenoid units in the tail, whereas the rodent form, coenzyme Q9 (CoQ9), has nine isoprenoid units. It is present in all organs, but is found in the highest concentrations in brain, heart, kidney, and liver tissue. ${ }^{3,6}$ It is synthesized endogenously, and approximately 3-5 mg per day are consumed in the diet. ${ }^{9}$

CoQ10 participates in electron transfer in the mitochondrial oxidative respiratory chain, producing adenosine triphosphate (ATP). ${ }^{2,10,11}$ It accepts electrons from complexes I and II, and is also a coenzyme for complex III (Figure 2). ${ }^{12}$ When reduced, it is a powerful antioxidant that prevents oxidative damage by free radicals, including oxidation of lipids within the mitochondrial membrane. ${ }^{1,2}$ CoQ10 also serves as an antioxidant by activating and increasing expression of mitochondrial uncoupling proteins (UCPs), an effect which is antiapoptotic and leads to a reduction in free radical generation. ${ }^{10,12}$ There is also emerging evidence for pleiotropic effects. It has also been shown to inhibit MPTP (1-methyl-4-phenyl-1,2,3,6-tetrahydropyridine)-induced interleukin-6 (IL-6), tumor necrosis factor- $\alpha$ (TNF- $\alpha$ ), and nuclear factor- $\mathrm{\kappa B}(\mathrm{NF}-\mathrm{\kappa B})$ expression, thus exerting an anti-inflammatory role, ${ }^{13}$ and more recently, gene expression profiling has revealed that CoQ10 influences the expression of hundreds of genes. It has been found in gene expression analysis and cell culture experiments to

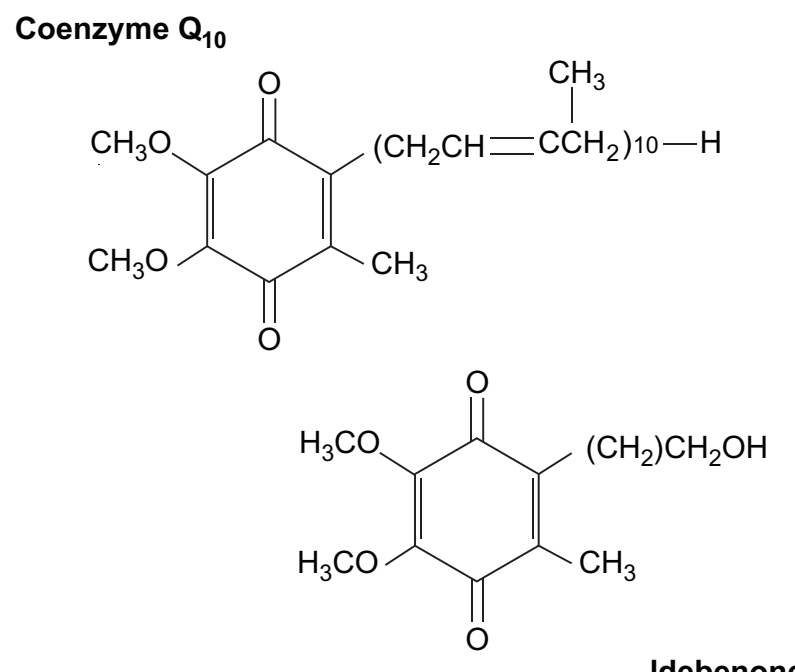

Figure I Chemical structures of Coenzyme QIO and its short-chain analog, idebenone. reduce the activity of inflammatory markers, suggesting it may have an anti-inflammatory effect via gene expression modification. ${ }^{14}$

\section{Production, pharmacokinetics, and bioavailability}

CoQ10 is available in several forms, including powder, suspension, oil solution, solubilized forms (All-Q and Q-Gel), as well as creams, tablets, wafers, and hard-shell or softgel capsules, all with different bioavailability. Recently a self-emulsifying drug delivery system (SEDDS) composed of oil and surfactant has been developed, ${ }^{15}$ as well as a new lipid-based formulation that self-assembles on contact with an aqueous phase into a colloid delivery system (VESIsorb, colloidal-Q10), ${ }^{16}$ both with the goal of improving bioavailability. It is available in more than 100 single-ingredient and combination-ingredient products. ${ }^{69}$ Additionally, idebenone, a short-chain analog that is less hydrophobic, has been produced (Figure 1). ${ }^{1}$ Prices for CoQ10 softgels vary widely typically ranging from US\$20-\$60 for 60 to $120100 \mathrm{mg}$ capsules or for $30400 \mathrm{mg}$ capsules.

In a study by Kalenikova and colleagues, administration of $10 \mathrm{mg} / \mathrm{kg}$ of both powder and solubilized forms resulted in maximum plasma concentrations in 3-4 hours. ${ }^{17}$ Using a lipid formulation and taking CoQ10 with food improves absorption. ${ }^{18}$ Over 24 hours, mean plasma concentrations of CoQ10 were significantly higher with the solubilized form. ${ }^{17}$ In humans, orally dosed CoQ10 causes two peaks in serum levels occurring at 5-6 hours and 24 hours; the second peak is smaller and is thought to be a result of uptake and secretion by the liver. The elimination half-life is estimated to be between 30 and 50 hours. Studies have shown that a dose of $30 \mathrm{mg}$ has negligible effects on plasma levels, ${ }^{18}$ while doses above $2,400 \mathrm{mg}$ do not increase plasma levels beyond the plateau reached at that dose. ${ }^{19}$

Importantly, CoQ10 crosses the blood-brain barrier in animal studies. Matthews and colleagues demonstrated a $30 \%-40 \%$ increase in cerebral cortex mitochondrial concentrations of CoQ9 and CoQ10 at 12 months in mice, ${ }^{2}$ and Smith and colleagues found brain levels of CoQ9 and CoQ10 to increase with oral supplementation in R6/2 mouse models of HD. ${ }^{8}$ Central nervous system penetration of oral CoQ10 in humans has not been studied.

\section{Consequences of CoQI 0 deficiency}

CoQ10 deficiency is a rare disorder with variable phenotypic presentations including pure myopathy, myopathy with 


\section{Mitochondrial electron transport chain}

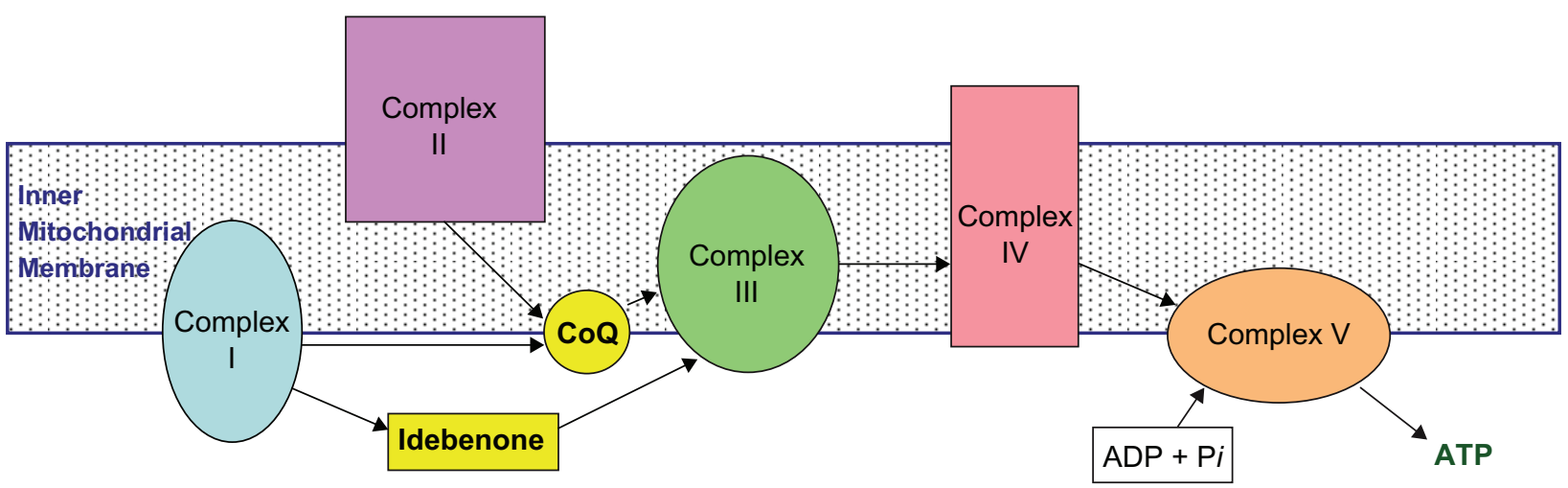

Figure $2 \mathrm{CoQ} 10$ in the mitochondrial electron transport chain. Coenzyme QI0 is a component of the electron transport chain located within the inner mitochondrial membrane, required for oxidative phosphorylation leading to ATP generation. It accepts electrons from complexes I (NADH-ubiquinone oxidoreductase) and II (succinate dehydrogenase) for transfer to complex III (ubiquinol-cytochrome c reductase). Idebenone is similarly involved in transfer of electrons from complex I to complex III.

encephalopathy, cerebellar atrophy with ataxia, and infantile multisystem disease including encephalopathy and nephropathy. ${ }^{20,21}$ The most common is the ataxic variant. ${ }^{22}$ Huntsman and colleagues recently reported a case of hypotonia and infantile spasms which they hypothesized to be a new phenotype of CoQ10 deficiency. ${ }^{23}$ Response to CoQ10 supplementation in this disorder is variable, though it is the best response of any mitochondrial encephalomyopathy to CoQ10 supplementation. ${ }^{22}$ The causes of primary CoQ10 deficiency are yet to be completely elucidated. Nine genes are presumed to be involved in CoQ10 biosynthesis, and as of now, mutations in three genes have been shown to result in primary CoQ10 deficiency: PDSS1, PDSS2, and COQ2. ${ }^{21}$ Duncan and colleagues found an autosomal recessive form of neonatalonset primary coenzyme Q10 deficiency resulting from a nonsense mutation in $C O Q 9 .{ }^{24}$

In a recent study of the pathophysiology of CoQ10 deficiency, fibroblasts from four patients were shown to have decreased activities of complexes I and II, complex III, and complex IV, reduced expression of mitochondrial proteins involved in oxidative phosphorylation, decreased mitochondrial membrane potential, increased production of reactive oxygen species, and reduced growth rate. These abnormalities reversed partially with coenzyme Q10 supplementation. ${ }^{25}$ Increased levels of lysosomal markers, enhanced expression of genes involved in autophagy, and findings on electron microscopy all provided evidence for massive degradation of dysfunctional mitochondria, which was eradicated with administration of antioxidants. Induced CoQ10 deficiency in cells genetically altered to lack autophagy resulted in apoptosis, indicating that the autophagy was likely protective. ${ }^{25}$

\section{Mitochondrial dysfunction and neurodegenerative disease: A rationale for testing CoQIO}

There are now multiple lines of evidence that strongly support mitochondrial dysfunction and oxidative stress as major contributors to pathogenesis of neurodegenerative diseases. These are well reviewed elsewhere, and some examples are briefly reviewed below. $3,5,10,11,26-37$

Increased markers of oxidative stress have been demonstrated in neurodegenerative disease, including elevated levels of 8-hydroxy-2'-deoxyguanosine (8OHdG) in Friedreich's ataxia (FA), amyotrophic lateral sclerosis (ALS), and PD. ${ }^{32,35,36-40}$ Elevated protein carbonyl formation and oxidized nitric oxide products with decreased glutathione peroxidase activity have been shown in ALS patients, while increased levels of malondialdehyde in plasma and decreased aconitase activities in cardiac and skeletal muscle have been shown in FA..$^{32,33,35,40,41}$ Evidence of mitochondrial dysfunction derives from animal models, studies of mitochondria from patients, postmortem pathology, identification of genetic defects in patients with neurodegenerative disease, and neuroimaging. For example, in $\mathrm{PD}$, there is diminished complex I activity in the substantia nigra, platelets, and skeletal muscle, ${ }^{10,28,42}$ and reduced activity of both complex I and II/III in platelet mitochondria. ${ }^{44,45}$ Moreover, the discovery of multiple PD genes whose function is linked to mitochondrial function or oxidative stress, although not proof, strongly supports 
a role for mitochondrial involvement in PD-associated neurodegeneration. In HD, there is evidence of deficiencies in complex I, II, and in some studies complex IV function, in multiple tissue types, including platelets, fibroblasts, and muscle cells, as well as brain. ${ }^{10,12,45,46}$ Postmortem deficiencies in key tricarboxylic acid (TCA) cycle enzymes, including pyruvate dehydrogenase, isocitrate dehydrogenase, and $\alpha$-ketoglutarate dehydrogenase, have been described in AD, indicating impaired mitochondrial function. ${ }^{10,47,48}$ In addition, deficiencies in the activities of complexes I, III, and IV have been described in the cortex, platelets, and lymphocytes of patients with AD. ${ }^{3,10}$ In FA patients, decreased activities of complexes I, II, and III have been found in the cardiac and skeletal muscle, either via biopsy or postmortem..$^{32,49,50}$

Coincident with aberrant mitochondrial function in PD, CoQ10 levels are significantly decreased in mitochondria from SN neurons and platelets in PD patients, and levels of CoQ10 have been shown to correlate with activity of complexes I and II/III. ${ }^{37}$ Decreased levels of CoQ10 in brain cortex relative to age-matched controls have also been demonstrated, though no reduction was found in the $\mathrm{SN}$, cerebellum, or striatum. ${ }^{51}$ In serum, there is a reduction in the ratio of reduced to oxidized CoQ10 in $\mathrm{PD}^{37,52,53}$ and ALS. ${ }^{38,40}$ However, serum total levels are no different from controls in $\mathrm{PD},{ }^{54} \mathrm{HD},{ }^{55}$ and ALS. ${ }^{40,56}$

\section{Evidence of neuroprotective effects of coenzyme Q 10 in vitro}

CoQ10 has been studied in multiple in vitro models of neuronal toxicity, with results that overall have supported a neuroprotective effect. In striatal slice cultures of mice, CoQ10 decreases 1-methyl-4-phenylpyridinium(MPP+)induced inhibition of complexes I and II, tyrosine hydroxylase, and hexokinase. ${ }^{30} \mathrm{CoQ} 10$ protects against rotenone-induced mitochondrial dysfunction and cell death in rat mesencephalic neurons and against iron-induced apoptosis in dopaminergic neurons. ${ }^{57,58}$ In neuronal cell models of oxidative stress, pre-treatment with CoQ10 preserves mitochondrial membrane potential and reduces generation of reactive oxygen species. ${ }^{59}$ Importantly, CoQ10 also protects human neuroblastoma (SHSY-5Y) cells against paraquat-induced mitochondrial dysfunction as well as against $\beta$-amyloid toxicity. ${ }^{60,61}$ Complex I and IV deficiencies in PD skin fibroblasts are improved by CoQ10. ${ }^{62}$ Administration of CoQ10 has also inhibited NMDA-receptor-induced cell death to a greater degree in cultured medium spiny projection neurons of YAC46 mice, transgenic models of HD, relative to those of wild type mice. ${ }^{63}$
Coenzyme Q10 has also been found to exert effects on $\alpha$-synuclein and $\beta$-amyloid fibrils in vitro, possibly due to binding with hydrophobic and antioxidant motifs. ${ }^{64,65}$ Along with other antioxidants, it destabilizes pre-formed $\beta$-amyloid fibrils in vitro, and inhibits formation and extension of $\beta$-amyloid fibrils. ${ }^{65}$ Similarly, it dose-dependently inhibits formation of $\alpha$-synuclein fibrils, and destabilizes pre-formed $\alpha$-synuclein fibrils. ${ }^{64}$

With regard to FA, succinate-reduced CoQ10 has been shown to protect membrane lipids and complex II against iron injury in human heart homogenate in vitro. ${ }^{7}$ Mitochondriatargeted CoQ10, MitoQ, prevented cell death in fibroblasts of FA patients which were treated with buthionine sulfoxime (BSO), an inhibitor of glutathione biosynthesis that causes death of FA fibroblasts but not of those of controls. ${ }^{66}$

\section{CoQ 10 effects in healthy animals and animal models of neurodegenerative disease}

Studies of the effects of CoQ10 have been performed on healthy animals as well as animal models of neurodegenerative disease, and the major studies are summarized in Table 1.

In healthy animals, oral administration of CoQ10 increases CoQ10 levels in the brain of older animals, whereas there is no effect on CoQ10 levels in young animals. In one study, feeding with $200 \mathrm{mg} / \mathrm{kg}$ of CoQ10 daily for $1-2$ months resulted in $30 \%-40 \%$ increases in cerebral cortex mitochondrial concentrations of CoQ (CoQ10 more than CoQ9) at 12 months; these increased levels were comparable to those of healthy 2-3-month-old rats. Similar feeding for one month at 24 months of age resulted in $10 \%$ increases in cerebral levels. ${ }^{2}$ In this same study, in 10 animals administered 3-nitropropionic acid, striatal lesions were attenuated by $90 \%$ in the CoQ10 group relative to the placebo group. ${ }^{2}$

Oral administration of CoQ10 for 7-10 days prior to injection of malonate in rats dose-dependently prevented malonate-induced ATP depletion at three hours, attenuated striatal lesions, and with nicotinamide prevented malonateinduced increases in lactate in vivo as assessed by MRS. ${ }^{67}$ Beal et al demonstrated that in 12-month-old mice pre-treated with CoQ10 for 4 weeks, CoQ10 protects against dopamine depletion and loss of tyrosine hydroxylase immunostained neurons induced by MPTP. ${ }^{27}$ Cleren and colleagues showed that in a chronic MPTP model, oral administration of CoQ10 protected against dopamine depletion, loss of TH-IR neurons in the $\mathrm{SN}$, and development of $\alpha$-synuclein aggregates. ${ }^{68}$ 
Table I Studies of effects of CoQIO on healthy animals and animal models of neurodegenerative disease

\begin{tabular}{|c|c|c|c|}
\hline Model & Dose & Effect & Ref \\
\hline Healthy rats & $200 \mathrm{mg} / \mathrm{kg}$ daily $\times \mathrm{I}-2$ months & $\begin{array}{l}\text { - } 30 \%-40 \% \text { increase in } \\
\text { cerebral mitochondrial CoQ } \\
\text { concentrations }\end{array}$ & Matthews ${ }^{2}$ \\
\hline \multicolumn{4}{|l|}{ Huntington's models } \\
\hline Malonate & $200 \mathrm{mg} / \mathrm{kg}$ daily $\times \mathrm{I}-2$ months & $\begin{array}{l}\text { - Prevented depletion of ATP } \\
\text { - Attenuated striatal lesions } \\
\text { - With nicotinamide, prevented } \\
\text { increase in lactate on MRS }\end{array}$ & Beal ${ }^{29}$ \\
\hline 3-NP & $200 \mathrm{mg} / \mathrm{kg}$ daily $\times \mathrm{I}-2$ months & $\begin{array}{l}\text { - Attenuation of striatal lesions } \\
\text { by } 90 \%\end{array}$ & Matthews $^{2}$ \\
\hline NI7I-82Q mice & $500 \mathrm{mg} / \mathrm{kg} /$ day & $\begin{array}{l}\text { - Diminished motor symptoms } \\
\text { - No effect on survival } \\
\text { - Effect augmented by } \\
\text { remacimide }\end{array}$ & Ferrante ${ }^{45}$ \\
\hline $\begin{array}{l}\mathrm{R} 6 / \mathrm{R} 2 \text { and } \mathrm{N} I 7 \mathrm{I}-82 \mathrm{Q} \\
\text { transgenic mice }\end{array}$ & $\begin{array}{l}\text { CoQ } 10400 \mathrm{mg} / \mathrm{kg} / \mathrm{day} \pm \\
\text { remacemide } 14 \mathrm{mg} / \mathrm{kg} / \text { day }\end{array}$ & $\begin{array}{l}\text { - Prolonged survival (additive) } \\
\text { - Delayed motor deficits, weight } \\
\text { loss, cerebral atrophy, and } \\
\text { neuronal intranuclear inclu- } \\
\text { sions }\end{array}$ & Ferrante ${ }^{45}$ \\
\hline R6/R2 transgenic mice & I,000 to $20,000 \mathrm{mg} / \mathrm{kg} /$ day & $\begin{array}{l}\text { - Prolonged survival } \\
\text { - Improved motor performance } \\
\text { - Reduced weight loss } \\
\text { - Decrease in cerebral and } \\
\text { striatal neuron atrophy, } \mathrm{Htt} \\
\text { aggregate accumulation }\end{array}$ & Smith $^{8}$ \\
\hline $\mathrm{R} 6 / 2$ transgenic mice & $\begin{array}{l}\text { CoQI0 }(0.2 \%) \text { and } \\
\text { minocycline } 5 \mathrm{mg} / \mathrm{kg} / \text { day }\end{array}$ & $\begin{array}{l}\text { - Extended survival } \\
\text { - Improved motor performance } \\
\text { - Amerliorated weight loss and } \\
\text { Htt aggregation (CoQ domi- } \\
\text { nant effect) }\end{array}$ & $\operatorname{Stack}^{71}$ \\
\hline 3-NP & $\begin{array}{l}\text { CoQI0 }(I \%) \text { and } \\
\text { creatine }(2 \%) \times \text { two weeks }\end{array}$ & $\begin{array}{l}\text { - Reduced striatal lesion volumes } \\
\text { (additive) }\end{array}$ & Yang $^{72}$ \\
\hline $\mathrm{R} 6 / 2$ transgenic mice & $\begin{array}{l}\text { CoQI0 }(I \%) \text { and } \\
\text { creatine }(2 \%) \times 9-I I \text { weeks }\end{array}$ & $\begin{array}{l}\text { - Improved motor performance } \\
\text { (additive) } \\
\text { - Extended survival (additive) }\end{array}$ & Yang ${ }^{72}$ \\
\hline \multicolumn{4}{|l|}{ Parkinson's models } \\
\hline MPTP & $\begin{array}{l}\text { CoQ10 } 200 \mathrm{mg} / \mathrm{kg} / \text { day } \times \\
\text { five weeks }\end{array}$ & $\begin{array}{l}\text { Protected against: } \\
\text { - Striatal dopamine depletion } \\
\text { - Loss of TH-IR neurons in the } \\
\text { SNpc }\end{array}$ & Beal $^{27}$ \\
\hline MPTP & $\begin{array}{l}\text { CoQ } 101600 \mathrm{mg} / \mathrm{kg} \times \\
3.5 \text { months }\end{array}$ & $\begin{array}{l}\text { Protected against: } \\
\text { - Dopamine depletion } \\
\text { - Loss of TH-IR neurons in the } \\
\text { SNpc } \\
\text { - Development of } \alpha \text {-synuclein } \\
\text { aggregates in SNpc }\end{array}$ & Cleren ${ }^{68}$ \\
\hline MPTP & $\begin{array}{l}\text { CoQI0 }(1 \%) \text { and } \\
\text { creatine }(2 \%) \times 5 \text { weeks }\end{array}$ & $\begin{array}{l}\text { Protected against: } \\
\text { - Dopamine depletion in the } \\
\text { striatum (additive) } \\
\text { - Loss of tyrosine hydroxylase } \\
\text { neurons in SNpc (additive) } \\
\text { - Lipid peroxidation } \\
\text { - } \alpha \text {-synuclein aggregates in SNpc }\end{array}$ & Yang ${ }^{72}$ \\
\hline
\end{tabular}


Table I (Continued)

\begin{tabular}{|c|c|c|c|}
\hline Model & Dose & Effect & Ref \\
\hline \multicolumn{4}{|l|}{ ALS models } \\
\hline $\begin{array}{l}\text { G93 A SODI transgenic } \\
\text { mouse }\end{array}$ & $\begin{array}{l}200 \text { mg/kg daily from day } 50 \\
\text { until end-stage disease }\end{array}$ & $\begin{array}{l}\text { - Significantly increased median } \\
\text { survival by } 4.4 \% \text { (six days) }\end{array}$ & Matthews ${ }^{2}$ \\
\hline \multicolumn{4}{|l|}{ Alzheimer models } \\
\hline $\begin{array}{l}\text { Aged APP, PSI,APP/PSI } \\
\text { transgenic mice }\end{array}$ & $2,400 \mathrm{mg} / \mathrm{kg} /$ day $\times 60$ days & $\begin{array}{l}\text { - Attenuated brain atrophy } \\
\text { as assessed by MRI in vivo }\end{array}$ & $\mathrm{Li}^{74}$ \\
\hline $\begin{array}{l}\text { Aged PSI transgenic } \\
\text { mouse }\end{array}$ & $\mathrm{I}, 200 \mathrm{mg} /$ day $\times 60$ days & $\begin{array}{l}\text { - Partially reduced A } \beta \text { overproduction } \\
\text { and intracellular cortical deposits } \\
\text { - Attenuation of elevated malondialdehyde } \\
\text { levels and downregulated SOD }\end{array}$ & Yang $^{73}$ \\
\hline TG19959 mice & $0.4 \%$ in diet & $\begin{array}{l}\text { - Protected against plaques } \\
\text { - Protected against memory loss } \\
\text { as assessed by Morris water maze task }\end{array}$ & Kipiani $^{75}$ \\
\hline
\end{tabular}

Abbreviations: mg, milligram;kg, kilogram; CoQ, coenzyme Q; CoQ I0, coenzyme QI0;ATP, adenosine triphosphate; MRS, magnetic resonance spectroscopy; 3-NP, 3-nitroproprionic acid; Htt, huntingtin; MPTP, I-methyl-4-phenyl-I,2,3,6-tetrahydropyridine; TH-IR, tyrosine hydroxylase-immunoreactive; SNpc, substantia nigra pars compacta; SOD, superoxide dismutase; A $\beta$, $\beta$-amyloid; APP, amyloid precursor protein; PSI, presenilin I; MRI, magnetic resonance imaging.

Rotenone-induced complex I inhibition in mice is attenuated by CoQ10 supplementation. ${ }^{13}$

In R6/2 and N171-82Q transgenic mouse models of HD, oral administration of coenzyme Q10 significantly prolonged survival and delayed motor deficits, weight loss, cerebral atrophy, and appearance of neuronal intranuclear inclusions. ${ }^{45}$ Brain levels of CoQ10 and CoQ9 were significantly lower in $\mathrm{R} 6 / 2$ mice relative to wild type mice, and oral supplementation with CoQ10 increased brain levels of CoQ9, CoQ10, and ATP, and reduced 8-hydroxy-2-deoxyguanosine levels. Mice which were administered high-dose CoQ10 (1000 to $20,000 \mathrm{mg}$ per $\mathrm{kg}$ per day) from age 28 days displayed prolonged survival, improved motor performance, reduced weight loss, decreased cerebral and striatal atrophy, and reduced huntingtin aggregate accumulation. ${ }^{8}$ In a study of N171-82Q mice, motor symptoms were diminished by oral CoQ10 $500 \mathrm{mg} / \mathrm{kg} /$ day beginning at the age of eight weeks, with peak effect at 13 weeks. No effect was observed on survival, but this parameter was confounded by a chow formulation that cut short the life expectancy of all animals. ${ }^{69,70}$ Combination therapy with remacemide augmented the motor performance and survival benefit, and attenuated the loss of striatal neurons. ${ }^{45} \mathrm{~A}$ study of the combination of minocycline and CoQ10 therapy in R6/2 mice yielded similar results; while the combination extended survival and improved motor performance greater than either agent alone, CoQ10 was found to play the dominant role in ameliorating weight loss and huntingtin aggregation. ${ }^{71}$ Similarly, in a transgenic mouse model of familial ALS that overexpresses $\mathrm{Cu} / \mathrm{Zn}$ superoxide dismutase (SOD1) with the G93 A mutation, treatment with
CoQ10 $200 \mathrm{mg} / \mathrm{kg} /$ day, started at 50 days of age, significantly increased mean life span by $4.4 \%$ (six days). ${ }^{2}$

A recent study aimed to determine whether co-administration of creatine and coenzyme Q10 would have additive effects in animal models of neurodegenerative disease. ${ }^{72}$ Additive neuroprotective effects were observed in the MPTP model against dopamine depletion in the striatum and loss of tyrosine hydroxylase neurons in the substantia nigra pars compacta (SNpc), in the 3-NP-treated rats with reduction of striatal lesion volumes, and in the transgenic R6/2 HD mice with improved motor performance and extended survival. In addition, the combination treatment resulted in a significant reduction of lipid peroxidation and alpha-synuclein accumulation in the SNpc in MPTP-treated mice, and reduction of lipid peroxidation and DNA oxidative damage in the striatum in the 3-NP rat model. ${ }^{72}$

In aged transgenic mice overexpressing Alzheimer presenilin 1-L235P mutation, treatment with CoQ10 1,200 mg per day for 60 days partially reduced A beta overproduction and intracellular A beta cortical deposits. In addition, increased levels of malondialdehyde and downregulation of SOD, both markers of oxidative stress seen in the transgenic mice, were ameliorated by CoQ10 treatment. ${ }^{73}$ Supplemental CoQ10 was also found to attenuate brain atrophy at 60 days, as assessed by MRI in vivo, in aged transgenic mice with amyloid precursor protein (APP) mutations. Single transgenic APP and presenilin 1 (PS1) mice as well as double transgenic APP/PS1 mice were treated with 2,400 mg/kg/day or placebo. The treated mice, including wild-type, exhibited significantly less atrophy in the hemispheres and hippocampus than those 
receiving placebo. ${ }^{74} \mathrm{~A}$ study by Kipiani and colleagues, currently in press, found that administration of CoQ10 in TG19959 transgenic mice, models of AD, conferred protection against plaques and memory loss, as assessed by the Morris water maze task. ${ }^{75}$

Activation of uncoupling proteins by CoQ10 has been associated with neuroprotection against MPTP toxicity in the substantia nigra of primates. ${ }^{10,11,76}$

\section{Clinical studies of CoQ 10 effects in neurodegenerative disease}

Given the encouraging results from preclinical studies, extensive efforts have been initiated in order to translate potential benefits into the clinical arena. These are summarized in Table 2, and are discussed below.

\section{Parkinson disease (PD)}

One of the first studies of the effects of CoQ10 in PD was an open-label trial in 10 subjects, using $200 \mathrm{mg}$ of CoQ10 daily for three months, that found no significant effect on Unified Parkinson's Disease Rating Scale (UPDRS) motor scores and motor testing. ${ }^{4}$ An open-label phase I trial of one month of daily CoQ10 in 15 subjects with PD was conducted to ascertain safety, tolerability, and effect on plasma levels. While the plasma levels were found to increase with doses of 400,600 , and $800 \mathrm{mg}$ per day, and the therapy was very well tolerated, no change in UPDRS scores or video examinations was observed. Interestingly, a trend towards increased mitochondrial complex I activity was noted. ${ }^{77}$

A pivotal randomized, double-blind, placebo controlled, multicenter phase II study of CoQ10 in 80 early untreated PD patients was published in 2002. ${ }^{78}$ This study, known as QE2 and conducted by Shults and colleagues, tested doses of 300,600 , and $1200 \mathrm{mg}$ daily, for up to 16 months or until disability requiring dopaminergic therapy had developed. Subjects also received 1,200 IU vitamin E per day. Subjects were well matched for gender, age, severity of PD (using UPDRS scores, Hoehn and Yahr Scale scores, and timed tapping scores), disability (Schwab and England Scale score), and intellectual function (Mini-Mental State Examination [MMSE]), at baseline. The primary endpoint was the change in total UPDRS score from baseline to final visit.CoQ10 supplementation was associated with up to $44 \%$ less functional decline in PD subjects $(P=0.09)$, most pronounced in part II of the UPDRS (ADLs). Evaluation at one month revealed no significant UPDRS difference, though there was benefit in UPDRS ADL scores. By eight months, differences between the groups were apparent, with those receiving 1,200 $\mathrm{mg}$ daily showing the greatest benefit. The secondary endpoint assessed each treatment group compared with placebo, and only the group receiving $1,200 \mathrm{mg}$ per day had a benefit that met significance $(P=0.04)$. Using the Schwab and England scale change as an endpoint, which measures independence, also demonstrated a benefit in those receiving CoQ10. However, administration of CoQ10 did not significantly increase time to disability requiring dopaminergic therapy. Of note, platelets from subjects assigned to CoQ10 arms had increased activity of complexes I, II, and III compared with patients receiving placebo $(P=0.04)$. Moreover, an assay of NADH to cytochrome-c reductase activity showed a significant increase in the patients treated with 1,200 mg CoQ10. ${ }^{78}$

One question arising from the QE2 study was whether higher doses of CoQ10 could provide a greater degree of benefit. An open label study of 17 patients was conducted to assess tolerability of high doses of CoQ10. Patients received escalating doses of CoQ10 from 1,200 $\mathrm{mg}$ to 3,000 mg per day over eight weeks. ${ }^{19}$ Thirteen of the 17 patients tolerated the maximum dose, but plasma levels reached a plateau at 2,400 mg per day, suggesting futility of studying doses higher than this. Video examinations showed no change. ${ }^{19}$ Using this data, the NINDS NET-PD investigators conducted a randomized, double-blind, futility trial of 2,400 mg of CoQ10 in early untreated PD. Placebo data from the DATATOP trial were used to establish the futility criteria, which were not met by CoQ10, indicating the need for further studies. ${ }^{79}$ There have, however, been questions surrounding the applicability of these historical placebo data, given that practice styles and patient expectations have altered, and this has made interpretation of the NET-PD data for CoQ10 more difficult. Finally, a NINDS-funded phase III, multicenter, randomized, placebo-controlled, double blind trial (NCT00740714, known as QE3) of CoQ10 at doses of $1200 \mathrm{mg}$ and $2400 \mathrm{mg}$ daily in combination with $1200 \mathrm{IU}$ daily vitamin $\mathrm{E}$, is enrolling a target of 600 subjects with early, unmedicated PD in the USA and Canada, in an effort to confirm and extend results from the QE2 trial.

An important point is that if the designs of the QE2 and QE3 clinical trials are to provide data bearing upon a neuroprotective effect, CoQ10 must be free of any symptomatic benefit that would cloud interpretation. In order to determine whether the effects of CoQ10 may be symptomatic rather than neuroprotective, Storch and colleagues conducted a multicenter, randomized, placebo-controlled, double-blind study of 106 PD patients, treated with CoQ10 300 mg/day for three months. ${ }^{80}$ All patients were within Hoehn and Yahr 
Table 2 Clinical trials of CoQ 10 in neurodegenerative disease

\begin{tabular}{|c|c|c|c|c|c|}
\hline Study type & $\mathbf{n}$ & Dose & Effect & $P$ value & Ref \\
\hline \multicolumn{6}{|l|}{ Parkinson's } \\
\hline Open label & 10 & $\begin{array}{l}200 \mathrm{mg} / \text { day } \times \text { three } \\
\text { months }\end{array}$ & $\begin{array}{l}\text { - No significant effect on } \\
\text { UPDRS and motor testing }\end{array}$ & - & Strijks ${ }^{4}$ \\
\hline Open label Phase I & 15 & $\begin{array}{l}400,600 \text {, and } 800 \mathrm{mg} / \text { day } \times \\
\text { one month }\end{array}$ & $\begin{array}{l}\text { - No change in UPDRS or video } \\
\text { - Increase in plasma CoQI0 } \\
\text { levels relative to controls } \\
\text { - Trend towards increased } \\
\text { complex I activity }\end{array}$ & $<0.05$ & Shults ${ }^{77}$ \\
\hline $\begin{array}{l}\text { Phase II (QE2) randomized, } \\
\text { double-blind, } \\
\text { placebo-controlled }\end{array}$ & 80 & $\begin{array}{l}300,600 \text {, and I } 200 \mathrm{mg} / \text { day, } \\
\text { up to } 16 \text { months with } \\
\text { Vitamin E I } 200 \mathrm{IU} / \text { day }\end{array}$ & $\begin{array}{l}\text { - } 44 \% \text { less functional decline, } \\
\text { most pronounced in ADLs } \\
\text { (part II UPDRS) } \\
\text { - Met significance in I,200 mg } \\
\text { dose group }(P=0.04) \\
\text { - Increased activity of electron } \\
\text { transport chain complexes } \\
\text { I \& III } \\
\text { - Did not decrease time to } \\
\text { levodopa }\end{array}$ & $\begin{array}{l}0.09 \\
0.04 \\
0.04\end{array}$ & Shults ${ }^{78}$ \\
\hline $\begin{array}{l}\text { Placebo-controlled, } \\
\text { double-blind }\end{array}$ & 28 & $360 \mathrm{mg} /$ day $\times$ four weeks & $\begin{array}{l}\text { - Mild but significant } \\
\text { improvement in UPDRS } \\
\text { - No improvement of motor } \\
\text { symptoms } \\
\text { - Significant improvement in } \\
\text { performance on color visual } \\
\text { testing }\end{array}$ & 0.008 & Muller ${ }^{81}$ \\
\hline Open label & 12 & $\begin{array}{l}\mathrm{I}, 000 \mathrm{mg} / \text { day } \times \text { three } \\
\text { months, then } \mathrm{I}, 500 \mathrm{mg} / \mathrm{day} \\
\times \text { three months }\end{array}$ & $\begin{array}{l}\text { - Minor but statistically } \\
\text { significant beneficial effect } \\
\text { on motor performance with } \\
\text { I,500 mg versus placebo }\end{array}$ & 0.004 & Horstink $^{82}$ \\
\hline $\begin{array}{l}\text { Randomized, placebo- } \\
\text { controlled, double-blind, } \\
\text { Levodopa-stratified }\end{array}$ & 106 & $\begin{array}{l}100 \mathrm{mg} \text { three times/day } \times \\
\text { three months }\end{array}$ & $\begin{array}{l}\text { - No significant change in } \\
\text { UPDRS - no symptomatic } \\
\text { effects }\end{array}$ & - & Storch ${ }^{80}$ \\
\hline Open label & 17 & $\begin{array}{l}\text { I,200 to } 3,000 \mathrm{mg} / \text { day over } \\
\text { eight weeks }\end{array}$ & $\begin{array}{l}\text { - Plateau of plasma levels at } \\
2,400 \mathrm{mg} / \text { day } \\
\text { - No change in video exam or } \\
\text { UPDRS }\end{array}$ & - & Shults ${ }^{19}$ \\
\hline Randomized, Double-blind & 71 & $2,400 \mathrm{mg} /$ day & - Did not meet futility criteria & 0.48 & NINDS-PET ${ }^{79}$ \\
\hline \multicolumn{6}{|l|}{ Huntington's } \\
\hline Open label & 10 & $\begin{array}{l}600-1,200 \mathrm{mg} / \text { day } \times \mathrm{six} \\
\text { months }\end{array}$ & $\begin{array}{l}\text { - No significant effect on clinical } \\
\text { scores }\end{array}$ & - & Feigin $^{83}$ \\
\hline Open label & 18 & $360 \mathrm{mg} /$ day for $>2$ months & $\begin{array}{l}\text { - Ameliorated cerebral cortex } \\
\text { lactate levels seen on MRS }\end{array}$ & $<0.00$ I & Koroshetz ${ }^{84}$ \\
\hline $\begin{array}{l}\text { Randomized, } \\
\text { placebo-controlled, } \\
\text { double-blind (CARE-HD) }\end{array}$ & 174 & $\begin{array}{l}300 \mathrm{mg} \text { twice } \\
\text { daily, } \times 30 \text { months, also in } \\
\text { combination with remacimide }\end{array}$ & $\begin{array}{l}\text { - Trend toward lessened decline in } \\
\text { total functional capacity of unified } \\
\text { HD rating scale, after one year }\end{array}$ & 0.15 & $\mathrm{HSG}^{86}$ \\
\hline \multicolumn{6}{|l|}{ Friedreich's ataxia } \\
\hline Open label & 10 & $\begin{array}{l}400 \mathrm{mg} / \text { day with Vitamin } \mathrm{E} \\
2,100 \mathrm{IU} / \text { day, } \times 47 \text { months }\end{array}$ & $\begin{array}{l}\text { - No improvement or } \\
\text { progression in neurologic } \\
\text { evaluation at six months } \\
\text { - At } 47 \text { months, compared to } \\
\text { cross-sectional data, slowed } \\
\text { progression of total ICARS and } \\
\text { kinetic scores for seven patients }\end{array}$ & $<0.01$ & Hart $^{89}$ \\
\hline
\end{tabular}

(Continued) 
Table 2 (Continued)

\begin{tabular}{|c|c|c|c|c|c|}
\hline Study type & $\mathbf{n}$ & Dose & Effect & $P$ value & Ref \\
\hline Double-blind, randomized & 50 & $\begin{array}{l}30 \mathrm{mg} / \text { day alone vs } \\
600 \mathrm{mg} / \text { day with vitamin } \mathrm{E} \\
2100 \mathrm{IU}\end{array}$ & $\begin{array}{l}\text { 49\% with improved ICARS } \\
\text { compared to cross-sectional } \\
\text { data }\end{array}$ & - & Cooper ${ }^{31}$ \\
\hline \multicolumn{6}{|l|}{ ALS } \\
\hline $\begin{array}{l}\text { Open label, placebo- } \\
\text { controlled }\end{array}$ & 31 & $\begin{array}{l}\text { Up to } 3000 \mathrm{mg} / \text { day } \\
\text { for eight months }\end{array}$ & $\begin{array}{l}\text { - Plateau at } 2400 \mathrm{mg} / \text { day } \\
\text { - No adverse effects } \\
\text { at } 3,000 \mathrm{mg} / \text { day }\end{array}$ & & Ferrante $^{92}$ \\
\hline Phase II trial Futility study & 185 & $\begin{array}{l}\mathrm{I}, 800 \mathrm{mg} / \text { day vs } \\
2,700 \mathrm{mg} / \text { day for } \\
\text { nine months }\end{array}$ & $\begin{array}{l}\text { - No significant differences } \\
\text { between CoQI0 and placebo } \\
\text { - Insufficient promise to warrant } \\
\text { phase III testing }\end{array}$ & - & Kaufmann ${ }^{93}$ \\
\hline \multicolumn{6}{|l|}{$\begin{array}{l}\text { Progressive supranuclear } \\
\text { palsy }\end{array}$} \\
\hline Phase II trial & 21 & $5 \mathrm{mg} / \mathrm{kg} /$ day $\times$ six weeks & $\begin{array}{l}\text { Ratio of high-energy to } \\
\text { low-energy phosphates } \\
\text { increased in occipital lobe, } \\
\text { trend in basal ganglia } \\
\text { - Significant mild improvement } \\
\text { in PSP rating scale and frontal } \\
\text { assessment battery }\end{array}$ & & Stamelou ${ }^{91}$ \\
\hline
\end{tabular}

Abbreviations: mg, milligrams; kg, kilograms; UPDRS, Unified Parkinson's Disease Rating Scale; CoQ I0, coenzyme Q I0; IU, international units; ADLs, activities of daily living; NINDS, National Institute of Neurological Disorders and Stroke; NET-PD, Neuroprotection Exploratory Trials in Parkinson's Disease; HD, Huntington's disease; HSG, Huntington's Study Group; ICARS, International Cooperative Ataxia Rating Scale; PSP, progressive supranuclear palsy; MRS,.

stages II-III, without motor complications, and were stratified by treatment with levodopa. No significant change in UPDRS scores, the primary endpoint, was observed, though serum CoQ10 levels were significantly elevated in all patients to a degree similar to levels attained with $1,200 \mathrm{mg}$ in the phase II trial reported by Shults and colleagues. The study authors concluded that adjunctive CoQ10 in mid-stage PD does not exert a symptomatic effect. ${ }^{80}$ Other small studies have suggested potential benefit, but these have been minor and of unclear significance. ${ }^{81,82}$

\section{Huntington's disease (HD)}

As in PD, there have been considerable efforts to determine whether CoQ10 could provide a neuroprotective effect. Ten subjects with HD were studied in a six-month open-label trial of tolerability and efficacy of CoQ10. Doses ranged from 600 to $1,200 \mathrm{mg}$ per day, with no significant effect on clinical scores at three or six months. ${ }^{83}$ In addition to clinical endpoints, proton magnetic resonance spectroscopy (1H-MRS) has been used in HD as a marker of CoQ10 effects. Increased lactate concentrations in the cerebral cortex and basal ganglia, as measured by $1 \mathrm{H}-\mathrm{MRS}$, have been shown to decrease with CoQ10 administration, and subsequently elevate upon withdrawal of treatment. ${ }^{84}$ This finding supports the predicted metabolic effect of oral CoQ10 in cerebral tissue, and is suggestive of an effect upon mitochondrial metabolism.
In 2001 the Huntington Study Group published the CARE-HD trial, a randomized, placebo-controlled, multicenter, double-blind trial of CoQ10 $300 \mathrm{mg}$ twice daily in 174 subjects with early HD. ${ }^{85}$ This therapy was compared with remacemide $600 \mathrm{mg}$ daily, combination therapy, or placebo. Patients were followed every four to five months for 30 months, at which point no significant reduction in functional decline was observed with any therapy. However, CoQ10 treatment resulted in a trend toward less decline in total functional capacity of the Unified HD Rating Scale (UHDRS), the primary endpoint of the trial. This benefit was observed only after a year of treatment, thus a symptomatic effect of CoQ10 is unlikely to explain it. Interestingly, secondary analyses of functional and cognitive decline showed significant slowing with CoQ10 treatment. While this study was powered to detect $35 \%-40 \%$ reduction in decline, detection of smaller benefits and even confirmation of the effects seen in this study would require a prohibitively large sample size. ${ }^{12,46,85}$

Pre-2CARE was a small, pilot, open-label, dose-ranging study in $20 \mathrm{HD}$ and six healthy subjects. ${ }^{86} \mathrm{CoQ} 10$ was administered at doses of 1,200 mg daily for one month, 2,400 mg daily for the next month, and then 3,600 mg daily continued for 12 weeks. An ongoing large phase III clinical trial of high dose CoQ10 in HD (2CARE - NCT00608881) is now testing these potential effects. This trial has an estimated 
enrollment of 608 patients, and will compare the effects of CoQ10 $2400 \mathrm{mg} /$ day with placebo for five years on change in total functional capacity.

\section{Friedreich's ataxia (FA)}

Interestingly, CoQ10 and its analog idebenone were studied in FA using cardiac prior to neurologic outcomes. As early as 1999 a 31\%-36\% reduction in septal thickness and 8\%-20\% reduction of left ventricle posterior wall was measured in three subjects with FA who were administered idebenone for 4-9 months. ${ }^{7}$ This finding was replicated in a larger cohort, in which $20 \%$ or greater reduction in left ventricular mass was demonstrated by echocardiogram in 17 out of 38 subjects given idebenone. ${ }^{87}$

Lodi and colleagues conducted a prospective, open-label study of 10 subjects with FA which evaluated both cardiac and neurologic parameters at three months, six months, and 47 months of treatment with CoQ10. ${ }^{88}$ Serum CoQ10 levels increased by 2.3 - to 7.4-fold in all patients. This revealed a significant increase in maximum rate of ATP production in skeletal muscle at three and six months, but no improvement of echocardiogram findings or neurologic evaluation, with CoQ10 $400 \mathrm{mg}$ per day and vitamin E 2100 IU per day. Neurologic evaluation of cerebellar signs using the International Cooperative Ataxia Rating Scale (ICARS) showed no progression, but no improvement either. ${ }^{49,88}$ Four years later, ICARS scores obtained on follow-up were compared with those of 77 subjects with FA stratified by GAA1 repeat size, to serve as controls. ${ }^{89} \mathrm{CoQ} 10$ administration resulted in slowed progression of the total ICARS score and kinetic scores for seven subjects, but no difference in progression of posture, gait, and hand dexterity scores. Improvement of cardiac and skeletal muscle bioenergetics found in the first study persisted over 47 months. ${ }^{50,89}$

A double-blind, randomized, but not placebo-controlled study of CoQ10 examined low versus high dose CoQ10 (30 mg versus $600 \mathrm{mg}$ ) in $50 \mathrm{FA}$ patients. ${ }^{31}$ The primary end-point was change in ICARS over two years, and again, cross-sectional data was used as a control group in lieu of a placebo arm. Serum CoQ10 levels were decreased at baseline in FA patients, and were significantly increased in both groups (3.4-fold in the low-dose group, 12.2-fold in the high-dose group). While there was no difference in rate of deterioration between the two treatment groups (the primary endpoint), $49 \%$ of all subjects receiving CoQ10 had improved ICARS scores when compared to cross-sectional data. Of note, this subgroup had significantly lower baseline serum CoQ10 levels. ${ }^{31}$
Recently Rinaldi and colleagues published a retrospective analysis of 35 patients with FA given idebenone $5 \mathrm{mg} / \mathrm{kg} /$ day for up to five years. Patients without left ventricular hypertension (LVH) prior to treatment had an increase in size of the interventricular septum and posterior wall thickness, while those with LVH prior to treatment had no change. The neurologic conditions of patients in both groups deteriorated. ${ }^{90}$

\section{Progressive supranuclear palsy (PSP)}

The clinical effects of CoQ10 in PSP, a rare disorder, have not yet been well-defined. However, a randomized, double-blind, placebo-controlled, phase II trial of CoQ10 $5 \mathrm{mg} / \mathrm{kg} /$ day in 21 probable PSP patients (stage $\leq$ III) for six weeks made use of MRS as a noninvasive measure of indices of metabolic function. Subjects receiving CoQ10 demonstrated decreased concentration of low-energy phosphates and increased ratios of high-energy to low-energy phosphates, as assessed by (31)P-MRS and (1)H-MRS, reaching significance in the occipital lobes and showing a trend in the basal ganglia. The PSP rating scale and frontal assessment battery improved slightly but significantly. Clinical assessments using UPDRS III, Hoehn and Yahr stage, MMSE, and Montgomery Asberg Depression Scale showed no change. ${ }^{91}$ Currently a phase III trial of CoQ10 in PSP patients is recruiting, with a goal of 60 patients undergoing treatment with CoQ10 for one year (NCT00382824).

\section{Amyotrophic lateral sclerosis (ALS)}

An open-label, placebo-controlled, dose escalation trial of CoQ10 was performed in 31 subjects with ALS, for the purpose of assessing safety and tolerability. Subjects were given doses of CoQ10 up to 3,000 mg/day for eight months. There was no significant difference in adverse effects between the treatment groups or among treatment groups. The serum level reached a plateau at the $2,400 \mathrm{mg}$ /day dosage, indicating that further studies need not exceed this dosage, though no increase in side effects were observed at $3,000 \mathrm{mg} /$ day. ${ }^{92} \mathrm{~A}$ phase II trial of CoQ10 1,800 $\mathrm{mg}$ daily or $2,700 \mathrm{mg}$ daily versus placebo in 185 ALS patients, with an adaptive design incorporating a futility test, found insufficient evidence to support a phase III trial. Using prespecified secondary analyses, no significant difference was found between CoQ10 2,700 mg daily and placebo. ${ }^{93}$

\section{Alzheimer disease (AD)}

No clinical trials have been performed using CoQ10 in AD. However, multiple trials of idebenone in AD were conducted 
in the 1990s, many demonstrating clinical benefit. In 1992 , Senin and colleagues published a multicenter, doubleblind, placebo-controlled trial of idebenone $45 \mathrm{mg}$ twice daily for four months in 102 elderly AD patients, finding a statistically significant benefit in memory, attention, and behavior. ${ }^{94}$ Bergamasco and colleagues conducted a multicenter, randomized, placebo-controlled, double-blind trial of idebenone treatment for 90 days in 92 patients, followed by optional long-term treatment, and found it to be effective on memory, attention, and orientation, and to slow the progressive worsening of the disease..$^{95}$ In 1997 , Weyer and colleagues randomized 300 patients to idebenone $30 \mathrm{mg}$ TID, $90 \mathrm{mg}$ TID, or placebo for six months, resulting in significant superiority of idebenone $90 \mathrm{mg}$ TID in clinical global response improvement, and the AD Assessment Scale cognitive (ADAS-Cog) and noncognitive (ADAS-Noncog) scores. ${ }^{96}$ Gutzmann conducted a two-year trial idebenone treatment for two years versus placebo for one year followed by one year of idebenone treatment, using the total ADAS score as a primary endpoint. He found that those started earlier on idebenone had superior efficacy than those started after one year of placebo, indicating a disease-modifying rather than symptomatic effect. ${ }^{97}$ However, in 2003, Thal and colleagues published a one-year, multicenter, doubleblind, placebo-controlled, randomized trial of idebenone 120,240 , or $360 \mathrm{mg}$ TID in 536 AD patients, with primary endpoint of ADAS-Cog and Clinical Global Impression of Change (CGIC) scores, demonstrating no significant difference in primary or secondary outcomes between the treatment groups. ${ }^{98}$

\section{Safety and tolerability}

In all of the studies mentioned above, most notably the study of up to $3,000 \mathrm{mg}$ /day in ALS patients by Ferrante and colleagues, no serious adverse effects have been reported, even at the highest doses. ${ }^{92}$ In the NET-PD study of CoQ10, CoQ10 was generally well tolerated. It was terminated early in four versus seven subjects in the placebo (Vitamin E alone) arm. Laboratory testing, including serum chemistry, blood counts, and urinalysis, did not differ between groups. There were four serious adverse events (SAEs) in the CoQ10 arm (diverticulosis exacerbation; gall bladder disorder; increased cough; recurrent kidney stone) versus six in the placebo arm (syncope; atrial fibrillation; attempted suicide; serious fall; elective urological surgery; TIA). None of these were thought to be related to the study intervention. The most common nongastrointestinal adverse events (AEs) in the CoQ10 group were headache (14\% vs 14\% placebo), upper respiratory infection ( $13 \%$ vs $14 \%$ placebo), and anxiety (13\% vs 14\% placebo). Gastrointestinal side-effects were nausea ( $11 \%$ vs $13 \%$ placebo), diarrhea ( $7 \%$ vs $3 \%$ placebo), gastro-esophageal reflux (7\% vs 4\% placebo) and heartburn (6\% vs 3\%). In Pre-2CARE, an open-label dose-ranging study in $20 \mathrm{HD}$ and eight healthy subjects using escalating doses over two months up to 3,600 mg for 12 weeks, six subjects withdrew prematurely (GI symptoms, three; worsened HD symptoms, two; fall, one) and five did not reach the $3,600 \mathrm{mg}$ dose. ${ }^{86}$ Gastrointestinal complaints were the most frequently reported AEs. In an eight-month tolerability study, 31 ALS subjects were given COQ10 in escalating doses over four months up to $3,000 \mathrm{mg}$ daily for another five months. ${ }^{92}$ Of the initial 31 enrollees, 24 completed the study at the maximal dose and one at a sub-maximal dose. No difference in plasma CoQ10 levels was detected in increases from 2,400 $\mathrm{mg}$ to $3000 \mathrm{mg}$ daily. Headache, rash, urinary tract infection, and peripheral edema were seen in $16.1 \%$, and abdominal pain, constipation, diarrhea, arthralgia, and infection in $12.9 \%$. Of nine SAE's, four occurred on CoQ10 but were judged unlikely to be related (myocardial infarction, dysphagia, hospice respite stay, respiratory disorder). Vital signs and laboratory tests were not significantly different (blood count, serum biochemistry, liver function tests, creatine kinase, urinalysis).

Overall, therefore, the most common side effect is mild gastrointestinal discomfort from CoQ10, and this occurs in less than 1\%. ${ }^{6,9}$ Isolated case studies regarding CoQ10 have reported decreased anticoagulant effect of warfarin, but this effect has not been confirmed in prospective studies. ${ }^{6} \mathrm{~A}$ recent trial of CoQ10 $200 \mathrm{mg}$ daily in pregnant women at risk for pre-eclampsia reported no adverse effects. ${ }^{99}$ Currently, no absolute contraindications to the use of CoQ10 exist.

\section{Conclusion}

There is an urgent need to identify agents that will provide neuroprotection and slow disease progression in neurodegenerative diseases that have an enormous collective impact on our society. Detailed and extensive pre-clinical studies have strongly supported CoQ10 as such a potential agent. This review outlines results from clinical trials that are encouraging, but have not yet clearly demonstrated its effect. One issue that the studies raise is the barrier to translating promising animal studies into human neurodegenerative disease. Improvements in animal models and development of relevant biomarkers to track disease progression and identify presymptomatic patients are ways in which this barrier is currently being addressed. It is also possible that response to 
CoQ10 may vary not only among different neurodegenerative diseases but also among subtypes of these diseases. Small sample sizes make it difficult to perform any meaningful regression analyses of the existing trials to stratify response by subtype. Future studies that will hopefully have larger sample sizes should aim to assess responses within subgroups of neurodegenerative diseases, defined either by phenotype, endophenotype, or genotype. Finally, the therapeutic range of CoQ10 in neurodegenerative disease may be much higher than the doses that have been studied, especially given that the central nervous system bioavailability of oral CoQ10 in humans is unknown. Indeed, the doses used in the most promising animal studies have been in the tens of thousands of milligrams per day. Ferrante's dose escalation trial, which demonstrated a serum plateau of CoQ10 levels at 2,400 mg per day, suggests that such high doses are not necessary, but studies using greater than 2,000 $\mathrm{mg}$ are needed. The phase III trial of CoQ10 in PD, QE3, is currently enrolling, and will shed some light on the question of a therapeutic range, with doses of 1,200 $\mathrm{mg}$ versus 2,400 $\mathrm{mg}$ of CoQ10.

\section{Disclosures}

The authors report no conflicts of interest in this work.

\section{References}

1. Geromel V, Rotig A, Munnich A, Rustin P. Coenzyme Q10 depletion is comparatively less detrimental to human cultured skin fibroblasts than respiratory chain complex deficiencies. Free Radic Res. 2002;36(4):375-379.

2. Matthews RT, Yang L, Browne S, Baik M, Beal MF. Coenzyme Q10 administration increases brain mitochondrial concentrations and exerts neuroprotective effects. Proc Natl Acad Sci U S A. 1998;95(15): 8892-8897.

3. Ogawa O, Zhu X, Perry G, Smith MA. Mitochondrial abnormalities and oxidative imbalance in neurodegenerative disease. Sci Aging Knowledge Environ. 2002;2002(41):pe16.

4. Strijks E, Kremer HP, Horstink MW. Q10 therapy in patients with idiopathic Parkinson's disease. Mol Aspects Med. 1997;18 Suppl: S237-S240.

5. Beal MF. Coenzyme Q10 administration and its potential for treatment of neurodegenerative diseases. Biofactors. 1999;9(2-4):261-266.

6. Bonakdar RA, Guarneri E. Coenzyme Q10. Am Fam Physician. 2005;72(6):1065-1070.

7. Rustin P, Munnich A, Rotig A. Quinone analogs prevent enzymes targeted in Friedreich ataxia from iron-induced injury in vitro. Biofactors. 1999;9(2-4):247-251.

8. Smith KM, Matson S, Matson WR, et al. Dose ranging and efficacy study of high-dose coenzyme Q10 formulations in Huntington's disease mice. Biochim Biophys Acta. 2006;1762(6):616-626.

9. Coenzyme Q10. Med Lett Drugs Ther. 2006;48(1229):19-20.

10. Chaturvedi RK, Beal MF. Mitochondrial approaches for neuroprotection. Ann N Y Acad Sci. 2008;1147:395-412.

11. Beal MF. Bioenergetic approaches for neuroprotection in Parkinson's disease. Ann Neurol. 2003;53 Supp1 3:S39-S47; discussion $\mathrm{S} 47-\mathrm{S} 38$.

12. Shults CW, Haas R. Clinical trials of coenzyme Q10 in neurological disorders. Biofactors. 2005;25(1-4):117-126.
13. Sharma SK, El Refaey H, Ebadi M. Complex-1 activity and 18F-DOPA uptake in genetically engineered mouse model of Parkinson's disease and the neuroprotective role of coenzyme Q10. Brain Res Bull. 2006;70(1):22-32.

14. Schmelzer C, Lindner I, Rimbach G, Niklowitz P, Menke T, Doring F. Functions of coenzyme Q10 in inflammation and gene expression. Biofactors. 2008;32(1-4):179-183.

15. Balakrishnan P, Lee BJ, Oh DH, et al. Enhanced oral bioavailability of Coenzyme Q10 by self-emulsifying drug delivery systems. Int J Pharm. 2009;374(1-2):66-72.

16. Liu ZX, Artmann C. Relative bioavailability comparison of different coenzyme Q10 formulations with a novel delivery system. Altern Ther Health Med. 2009;15(2):42-46.

17. Kalenikova EI, Gorodetskaya EA, Medvedev OS. Pharmacokinetics of coenzyme q10. Bull Exp Biol Med. 2008;146(3):313-316.

18. Beal MF, Shults CW. Effects of Coenzyme Q10 in Huntington's disease and early Parkinson's disease. Biofactors. 2003;18(1-4): 153-161.

19. Shults CW, Flint Beal M, Song D, Fontaine D. Pilot trial of high dosages of coenzyme Q10 in patients with Parkinson's disease. Exp Neurol. 2004;188(2):491-494.

20. Quinzii CM, Lopez LC, Naini A, DiMauro S, Hirano M. Human CoQ10 deficiencies. Biofactors. 2008;32(1-4):113-118.

21. DiMauro S, Quinzii CM, Hirano M. Mutations in coenzyme Q10 biosynthetic genes. J Clin Invest. 2007;117(3):587-589.

22. Montero R, Pineda M, Aracil A, et al. Clinical, biochemical and molecular aspects of cerebellar ataxia and Coenzyme Q10 deficiency. Cerebellum. 2007;6(2):118-122.

23. Huntsman RJ, Lemire EG, Dunham CP. Hypotonia and infantile spasms: a new phenotype of coenzyme Q10 deficiency? Can J Neurol Sci. 2009;36(1):105-108.

24. Duncan AJ, Bitner-Glindzicz M, Meunier B, et al. A nonsense mutation in COQ9 causes autosomal-recessive neonatal-onset primary coenzyme Q10 deficiency: a potentially treatable form of mitochondria disease. Am J Hum Genet. 2009;84(5):558-566.

25. Rodriguez-Hernandez A, Cordero MD, Salviati L, et al. Coenzyme Q deficiency triggers mitochondria degradation by mitophagy. Autophagy. 2009;5(1):19-32.

26. Henchcliffe C, Beal MF. Mitochondrial biology and oxidative stress in Parkinson disease pathogenesis. Nat Clin Pract Neurol. 2008; 4(11):600-609.

27. Beal MF, Matthews RT, Tieleman A, Shults CW. Coenzyme Q10 attenuates the 1-methyl-4-phenyl-1,2,3,tetrahydropyridine (MPTP) induced loss of striatal dopamine and dopaminergic axons in aged mice. Brain Res. 1998;783(1):109-114.

28. Koller WC, Cersosimo MG. Neuroprotection in Parkinson's disease: an elusive goal. Curr Neurol Neurosci Rep. 2004;4(4):277-283.

29. Beal MF. Neurochemistry and toxin models in Huntington's disease. Curr Opin Neurol. 1994;7(6):542-547.

30. Gille G, Hung ST, Reichmann H, Rausch WD. Oxidative stress to dopaminergic neurons as models of Parkinson's disease. Ann NY Acad Sci. 2004;1018:533-540.

31. Cooper JM, Korlipara LV, Hart PE, Bradley JL, Schapira AH. Coenzyme Q10 and vitamin E deficiency in Friedreich's ataxia: predictor of efficacy of vitamin E and coenzyme Q10 therapy. Eur J Neurol. 2008;15(12):1371-1379.

32. Cooper JM, Schapira AH. Friedreich's Ataxia: disease mechanisms, antioxidant and Coenzyme Q10 therapy. Biofactors. 2003;18(1-4): 163-171.

33. Cooper JM, Schapira AH. Friedreich's ataxia: coenzyme Q10 and vitamin E therapy. Mitochondrion. 2007;7(Supp1):S127-S135.

34. Shults CW, Haas RH, Beal MF. A possible role of coenzyme Q10 in the etiology and treatment of Parkinson's disease. Biofactors. 1999; 9(2-4):267-272.

35. Strong MJ, Pattee GL. Creatine and coenzyme Q10 in the treatment of ALS. Amyotroph Lateral Scler Other Motor Neuron Disord. 2000;1(Suppl 4):17-20. 
36. Bogdanov MB, Ramos LE, Xu Z, Beal MF. Elevated "hydroxyl radical" generation in vivo in an animal model of amyotrophic lateral sclerosis. J Neurochem. 1998;71(3):1321-1324.

37. Shults CW, Haas RH, Passov D, Beal MF. Coenzyme Q10 levels correlate with the activities of complexes I and II/III in mitochondria from parkinsonian and nonparkinsonian subjects. Ann Neurol. 1997;42(2):261-264.

38. Murata T, Ohtsuka C, Terayama Y. Increased mitochondrial oxidative damage and oxidative DNA damage contributes to the neurodegenerative process in sporadic amyotrophic lateral sclerosis. Free Radic Res. 2008;42(3):221-225.

39. Bogdanov M, Matson WR, Wang L, et al. Metabolomic profiling to develop blood biomarkers for Parkinson's disease. Brain. 2008; 131(Pt 2):389-396.

40. Sohmiya M, Tanaka M, Suzuki Y, Tanino Y, Okamoto K, Yamamoto Y. An increase of oxidized coenzyme Q-10 occurs in the plasma of sporadic ALS patients. J Neurol Sci. 2005;228(1):49-53.

41. Tohgi H, Abe T, Yamazaki K, Murata T, Ishizaki E, Isobe C. Increase in oxidized NO products and reduction in oxidized glutathione in cerebrospinal fluid from patients with sporadic form of amyotrophic lateral sclerosis. Neurosci Lett. 1999;260(3):204-206.

42. Schapira AH, Mann VM, Cooper JM, et al. Anatomic and disease specificity of NADH CoQ1 reductase (complex I) deficiency in Parkinson's disease. J Neurochem. 1990;55(6):2142-2145.

43. Haas RH, Nasirian F, Nakano K, et al. Low platelet mitochondrial complex I and complex II/III activity in early untreated Parkinson's disease. Ann Neurol. 1995;37(6):714-722.

44. Benecke R, Strumper P, Weiss H. Electron transfer complexes I and IV of platelets are abnormal in Parkinson's disease but normal in Parkinson-plus syndromes. Brain. 1993;116(Pt 6):1451-1463.

45. Ferrante RJ, Andreassen OA, Dedeoglu A, et al. Therapeutic effects of coenzyme Q10 and remacemide in transgenic mouse models of Huntington's disease. J Neurosci. 2002;22(5):1592-1599.

46. del Hoyo P, Garcia-Redondo A, de Bustos F, et al. Oxidative stress in skin fibroblasts cultures of patients with Huntington's disease. Neurochem Res. 2006;31(9):1103-1109.

47. Huang HM, Zhang H, Xu H, Gibson GE. Inhibition of the alpha-ketoglutarate dehydrogenase complex alters mitochondrial function and cellular calcium regulation. Biochim Biophys Acta. 2003;1637(1): 119-126.

48. Bubber P, Haroutunian V, Fisch G, Blass JP, Gibson GE. Mitochondrial abnormalities in Alzheimer brain: mechanistic implications. Ann Neurol. 2005;57(5):695-703.

49. Lodi R, Rajagopalan B, Bradley JL, et al. Mitochondrial dysfunction in Friedreich's ataxia: from pathogenesis to treatment perspectives. Free Radic Res. 2002;36(4):461-466.

50. Lodi R, Tonon C, Calabrese V, Schapira AH. Friedreich's ataxia: from disease mechanisms to therapeutic interventions. Antioxid Redox Signal. 2006;8(3-4):438-443.

51. Hargreaves IP, Lane A, Sleiman PM. The coenzyme Q10 status of the brain regions of Parkinson's disease patients. Neurosci Lett. 2008;447(1):17-19.

52. Gotz ME, Gerstner A, Harth R, et al. Altered redox state of platelet coenzyme Q10 in Parkinson's disease. J Neural Transm. 2000;107(1):41-48

53. Sohmiya M, Tanaka M, Tak NW, et al. Redox status of plasma coenzyme Q10 indicates elevated systemic oxidative stress in Parkinson's disease. J Neurol Sci. 2004;223(2):161-166.

54. Jimenez-Jimenez FJ, Molina JA, de Bustos F, et al. Serum levels of coenzyme Q10 in patients with Parkinson's disease. J Neural Transm. 2000;107(2):177-181

55. Andrich J, Saft C, Gerlach M, et al. Coenzyme Q10 serum levels in Huntington's disease. J Neural Transm Suppl. 2004;(68):111-116.

56. Molina JA, de Bustos F, Jimenez-Jimenez FJ, et al. Serum levels of coenzyme Q10 in patients with amyotrophic lateral sclerosis. J Neural Transm. 2000;107(8-9):1021-1026.

57. Moon Y, Lee KH, Park JH, Geum D, Kim K. Mitochondrial membrane depolarization and the selective death of dopaminergic neurons by rotenone: protective effect of coenzyme Q10. J Neurochem. 2005;93(5):1199-1208.
58. Kooncumchoo P, Sharma S, Porter J, Govitrapong P, Ebadi M. Coenzyme Q(10) provides neuroprotection in iron-induced apoptosis in dopaminergic neurons. J Mol Neurosci. 2006;28(2):125-141.

59. Somayajulu M, McCarthy S, Hung M, Sikorska M, Borowy-Borowski H, Pandey S. Role of mitochondria in neuronal cell death induced by oxidative stress; neuroprotection by Coenzyme Q10. Neurobiol Dis. 2005;18(3):618-627.

60. Li G, Zou LY, Cao CM, Yang ES. Coenzyme Q10 protects SHSY5Y neuronal cells from beta amyloid toxicity and oxygen-glucose deprivation by inhibiting the opening of the mitochondrial permeability transition pore. Biofactors. 2005;25(1-4):97-107.

61. McCarthy S, Somayajulu M, Sikorska M, Borowy-Borowski H, Pandey S. Paraquat induces oxidative stress and neuronal cell death; neuroprotection by water-soluble Coenzyme Q10. Toxicol Appl Pharmacol. 2004;201(1):21-31.

62. Winkler-Stuck K, Wiedemann FR, Wallesch CW, Kunz WS. Effect of coenzyme Q10 on the mitochondrial function of skin fibroblasts from Parkinson patients. J Neurol Sci. 2004;220(1-2):41-48.

63. Zeron MM, Fernandes HB, Krebs C, et al. Potentiation of NMDA receptor-mediated excitotoxicity linked with intrinsic apoptotic pathway in YAC transgenic mouse model of Huntington's disease. Mol Cell Neurosci. 2004;25(3):469-479.

64. Ono K, Yamada M. Vitamin A potently destabilizes preformed alphasynuclein fibrils in vitro: implications for Lewy body diseases. Neurobiol Dis. 2007;25(2):446-454.

65. Ono K, Hasegawa K, Naiki H, Yamada M. Preformed beta-amyloid fibrils are destabilized by coenzyme Q10 in vitro. Biochem Biophys Res Commun. 2005;330(1):111-116.

66. Jauslin ML, Meier T, Smith RA, Murphy MP. Mitochondria-targeted antioxidants protect Friedreich Ataxia fibroblasts from endogenous oxidative stress more effectively than untargeted antioxidants. FASEBJ. 2003;17(13):1972-1974.

67. Beal MF, Henshaw DR, Jenkins BG, Rosen BR, Schulz JB. Coenzyme Q10 and nicotinamide block striatal lesions produced by the mitochondrial toxin malonate. Ann Neurol. 1994;36(6):882-888.

68. Cleren C, Yang L, Lorenzo B, et al. Therapeutic effects of coenzyme Q10 (CoQ10) and reduced CoQ10 in the MPTP model of Parkinsonism. J Neurochem. 2008;104(6):1613-1621.

69. Schilling G, Coonfield ML, Ross CA, Borchelt DR. Coenzyme Q10 and remacemide hydrochloride ameliorate motor deficits in a Huntington's disease transgenic mouse model. Neurosci Lett. 2001;315(3):149-153.

70. Schilling G, Savonenko AV, Coonfield ML, et al. Environmental, pharmacological, and genetic modulation of the HD phenotype in transgenic mice. Exp Neurol. 2004;187(1):137-149.

71. Stack EC, Smith KM, Ryu H, et al. Combination therapy using minocycline and coenzyme Q10 in R6/2 transgenic Huntington's disease mice. Biochim Biophys Acta. 2006;1762(3):373-380.

72. Yang L, Calingasan NY, Wille EJ, et al. Combination therapy with coenzyme Q10 and creatine produces additive neuroprotective effects in models of Parkinson's and Huntington's diseases. J Neurochem. 2009;109(5):1427-1439.

73. Yang X, Yang Y, Li G, Wang J, Yang ES. Coenzyme Q10 attenuates beta-amyloid pathology in the aged transgenic mice with Alzheimer presenilin 1 mutation. J Mol Neurosci. 2008;34(2):165-171.

74. Li G, Jack CR, Yang XF, Yang ES. Diet supplement CoQ10 delays brain atrophy in aged transgenic mice with mutations in the amyloid precursor protein: an in vivo volume MRI study. Biofactors. 2008;32(1-4): 169-178.

75. Kipiani K, Dumont M, Yu F, et al. Coenzyme Q10 decreases amyloid pathology and improves behavior in a transgenic mouse model of Alzheimer's disease. 2009. Personal Communication.

76. Schulz JB, Henshaw DR, Matthews RT, Beal MF. Coenzyme Q10 and nicotinamide and a free radical spin trap protect against MPTP neurotoxicity. Exp Neurol. 1995;132(2):279-283.

77. Shults CW, Beal MF, Fontaine D, Nakano K, Haas RH. Absorption, tolerability, and effects on mitochondrial activity of oral coenzyme Q10 in parkinsonian patients. Neurology. 1998;50(3):793-795. 
78. Shults CW, Oakes D, Kieburtz K, et al. Effects of coenzyme Q10 in early Parkinson disease: evidence of slowing of the functional decline. Arch Neurol. 2002;59(10):1541-1550.

79. A randomized clinical trial of coenzyme Q10 and GPI-1485 in early Parkinson disease. Neurology. 2007;68(1):20-28.

80. Storch A. Coenzyme Q10 in Parkinson's disease. Symptomatic or neuroprotective effects? Nervenarzt. 2007;78(12):1378-1382.

81. Muller T, Buttner T, Gholipour AF, Kuhn W. Coenzyme Q10 supplementation provides mild symptomatic benefit in patients with Parkinson's disease. Neurosci Lett. 2003;341(3):201-204.

82. Horstink MW, van Engelen BG. The effect of coenzyme Q10 therapy in Parkinson disease could be symptomatic. Arch Neurol. 2003;60(8):1170-1172; author reply 1172-1173.

83. Feigin A, Kieburtz K, Como P, et al. Assessment of coenzyme Q10 tolerability in Huntington's disease. Mov Disord. 1996;11(3):321-323.

84. Koroshetz WJ, Jenkins BG, Rosen BR, Beal MF. Energy metabolism defects in Huntington's disease and effects of coenzyme Q10. Ann Neurol. 1997;41(2):160-165.

85. A randomized, placebo-controlled trial of coenzyme Q10 and remacemide in Huntington's disease. Neurology. 2001;57(3):397-404.

86. HSG. PRE2CARE: A dosage ranging trial of coenzyme Q10 in Huntington's disease and normal subjects [abstract]. Cambridge, MA: HDF Biennial Symposia; 2005.

87. Hausse AO, Aggoun Y, Bonnet D, et al. Idebenone and reduced cardiac hypertrophy in Friedreich's ataxia. Heart. 2002;87(4):346-349.

88. Lodi R, Hart PE, Rajagopalan B, et al. Antioxidant treatment improves in vivo cardiac and skeletal muscle bioenergetics in patients with Friedreich's ataxia. Ann Neurol. 2001;49(5):590-596.

89. Hart PE, Lodi R, Rajagopalan B, et al. Antioxidant treatment of patients with Friedreich ataxia: four-year follow-up. Arch Neurol. 2005;62(4):621-626.
90. Rinaldi C, Tucci T, Maione S, Giunta A, De Michele G, Filla A. Low-dose idebenone treatment in Friedreich's ataxia with and without cardiac hypertrophy. J Neurol. 2009;256(9):1434-1437.

91. Stamelou M, Reuss A, Pilatus U, et al. Short-term effects of coenzyme Q10 in progressive supranuclear palsy: a randomized, placebocontrolled trial. Mov Disord. 2008;23(7):942-949.

92. Ferrante KL, Shefner J, Zhang H, et al. Tolerance of high-dose (3,000 mg/day) coenzyme Q10 in ALS. Neurology. 2005;65(11): 1834-1836.

93. Kaufmann P, Thompson JLP, Levy G, et al. Phase II trial of CoQ10 for ALS finds insufficient evidence to justify phase III. Ann Neurol. 2009;66(2):235-244.

94. Senin U, Parnetti L, Barbagallo-Sangiorgi G, et al. Idebenone in senile dementia of Alzheimer type: a multicentre study. Arch Gerontol Geriatr. 1992;15(3):249-260.

95. Bergamasco B, Scarzella L, La Commare P. Idebenone, a new drug in the treatment of cognitive impairment in patients with dementia of the Alzheimer type. Funct Neurol. 1994;9(3):161-168.

96. Weyer G, Babej-Dolle RM, Hadler D, Hofmann S, Herrmann WM. A controlled study of 2 doses of idebenone in the treatment of Alzheimer's disease. Neuropsychobiology. 1997;36(2):73-82.

97. Gutzmann H, Hadler D. Sustained efficacy and safety of idebenone in the treatment of Alzheimer's disease: update on a 2-year double-blind multicentre study. J Neural Transm Suppl. 1998;54:301-310.

98. Thal LJ, Grundman M, Berg J, et al. Idebenone treatment fails to slow cognitive decline in Alzheimer's disease. Neurology. 2003;61(11): 1498-1502.

99. Teran E, Hernandez I, Nieto B, Tavara R, Ocampo JE, Calle A. Coenzyme Q10 supplementation during pregnancy reduces the risk of pre-eclampsia. Int J Gynaecol Obstet. 2009;105(1):43-45.
Neuropsychiatric Disease and Treatment

\section{Publish your work in this journal}

Neuropsychiatric Disease and Treatment is an international, peerreviewed journal of clinical therapeutics and pharmacology focusing on concise rapid reporting of clinical or pre-clinical studies on a range of neuropsychiatric and neurological disorders. This journal is indexed on PubMed Central, the 'PsycINFO' database and CAS, and is the official

\section{Dovepress}

journal of The International Neuropsychiatric Association (INA). The manuscript management system is completely online and includes a very quick and fair peer-review system, which is all easy to use. Visit $\mathrm{http}: / /$ www.dovepress.com/testimonials.php to read real quotes from published authors. 